\title{
HYPOGLYCEMIC AND HYPOLIPIDEMIC EFFECTS OF Corchorus olitorius LEAVES AS A FOOD SUPPLEMENT ON RATS WITH ALLOXAN-INDUCED DIABET
}

\author{
G. N. ANYASOR, O. O. ADEKANYE, O. T. ADEYEMI, O. OSILESI \\ Department of Biochemistry, Benjamin S. Carson School of Medicine, \\ Babcock University, Ilisan-Remo, Ogun State, Nigeria; \\ e-mail: olaoluwatemi@yahoo.com
}

Received: 16 October 2019; Accepted: 15 May 2020

Corchorus olitorius is a species of shrub in the family Malvaceae known to have rich sources of chemical compounds. The leaves of this plant are locally consumed as a vegetable and as a remedy in Africa, Middle East and Southern Asia. This study was designed to evaluate the hypoglycemic and hypolipidemic effects of C. olitorius leaves sample given for 14 days as a food supplement to rats with alloxan-induced diabetes. Twenty one male albino rats weighing 150-200 g were randomly assigned into three groups: 1 -control rats; 2 -diabetic rats; 3 -diabetic rats fed with C. olitorius leaves as supplement. Phytochemical analysis of C. olitorius leaves ethanolic extract revealed the presence of alkaloids, anthraquinone, cardiac glycosides, saponins, tannins, phenols, phlobatannins and flavonoids. Diabetic rats fed with C. olitorius leaves as a supplement were shown to have significantly $(P<0.01)$ decreased plasma glucose, LDL-cholesterol, total cholesterol and triglycerides levels when compared with untreated diabetic rats. The findings from this study indicated that C. olitorius leaf possesses hypoglycemic and hypolipidemic properties.

Keywords: Corchorus olitorius, alloxan-induced diabetes, hypoglycemic and hypolipidemic effects, cholesterol, triglycerides.

Corchorus olitorius L. is a vegetable plant of the Family of Malvaceae, formerly called Tiliaceae, which is commonly known as "Jews mallow". It is a tall, annual plant that thrives in any soil-type. The jute fiber from Corchorus is the most widely cultivated vegetable fiber after cotton $[1,2]$. The leaves of $C$. olitorius have been a staple Egyptian vegetable which is also used as cuisines in Africa, Southern Asia, and Middle East. It has a mucilaginous texture when cooked. The seeds are used as a flavoring agent while the dried leaves are used for preparation of herbal tea [3]. In Nigerian cuisine, especially amongst the South-Westerners, C. olitorius leaves are commonly used as vegetable in preparation of stew based diet known as 'ewedu'. In Sierra Leone it is known as krain krain (or crain crain) and is cooked as stew. In the Philippines, C. olitorius is known as "saluyot" and it is consumed as a leafy vegetable together with bamboo shoots $[3,4]$.
Diabetes mellitus is characterized by a hyperglycemic condition induced by insulin insensitivity or inappropriate production of insulin by the beta cells of Islet of Langerhans found in the pancreas [5]. Chronic diabetes have been shown to compromise the integrity of organ architecture with an eventual loss of cellular function. Several synthetic drugs including sulfonylurea are been used clinically to manage the onset of diabetes, however, these drugs are often associated with adverse effects to the body system [6], hence the need for an alternative source of treatment with minimal adverse effects. Data exist in literature on the care of diabetes using various extracted medicinal plant products. However, consuming plant material as food for therapeutic purposes may play an important role in providing adequate health benefits to diabetic patients. Thus, this study was designed to investigate the hypoglycemic and hypolipidemic effects of compounded

(C) 2020 Nduka A. G. et al. This is an open-access article distributed under the terms of the Creative Commons Attribution License, which permits unrestricted use, distribution, and reproduction in any medium, provided the original author and source are credited. 
C. olitorius leave as food supplement fed to alloxaninduced diabetic rats.

\section{Materials and Methods}

\section{Sample collection and identification}

Fresh leaves of $C$. olitorious were procured from Awolowo market, Shagamu, Ogun State, Nigeria. It was identified by Professor Edward B. Esan, a plant scientist in the Department of Biosciences and Biotechnology, Babcock University.

Phytochemical evaluation. Ethanolic extract of C. olitorius leaf was screened for the presence of flavonoid, saponin and tannins using method described by Trease and Evans [7], Harbone [8] and Sofowora [9].

Plant extraction procedure. The plant extract used for phytochemical screening was obtained by soaking $100 \mathrm{~g}$ of the dry, pulverized plant sample in $600 \mathrm{ml}$ of $50 \%$ ethanol for $72 \mathrm{~h}$ after which it was filtered and the filtrate got was concentrated using the rotary evaporator (Buchi Rotavapor RE; Switzerland) at $40^{\circ} \mathrm{C}$. The concentrate was gently evaporated over a water bath in order to obtain an ethanolfree concentrate. This concentrate was used for the phytochemical analysis.

Test for flavonoids. One millilitre of water was added to $0.5 \mathrm{~g}$ of the sample and was subsequently filtered. Afterwards, $5 \mathrm{ml}$ of dilute ammonia followed by $1 \mathrm{ml}$ of concentrated sulphuric acid was added to the filtrate. A yellow colouration was taken as an evidence for the presence of flavonoids.

Test for saponins. Extract (0.5 g) was shaken with $5 \mathrm{ml}$ of water in a test tube. Frothing which persists on warming was taken as preliminary evidence for the presence of saponin.

Test tannins. About $0.5 \mathrm{~g}$ of pulverized sample was stirred with $1 \mathrm{ml}$ of distilled water and filtered. The 5 drops of $1 \%$ ferric chloride was added to the filtrate. A blue-black, green or blue-green precipitate was taken as evidence for the presence of tannins. The Corchorus sample was screened qualitatively for the presence of phytochemicals. The screening was carried out using the ethanolic extracts of the plants.

\section{Proximate analysis}

The proximate moisture, carbohydrate, crude ash and fat content were determined following the standard methods as described by Association of Official Analytical Chemist (AOAC) [10].
Moisture content. The empty petri dish was dried in the oven and cooled in a desiccator. The weight of the empty dish was recorded and $5 \mathrm{~g}$ of the fresh leaf samples were weighed into the dish. The leaves were dried in a hot air-oven for $2 \mathrm{~h}$ at $100{ }^{\circ} \mathrm{C}$ after which it was removed and allowed to cool in a desiccator for $30 \mathrm{~min}$. The cooled dish together with its contents was weighed. The dish was returned into the oven and dried for another $30 \mathrm{~min}$ after which it was cooled and weighed again. The process was repeated until a constant final weight was recorded and the moisture content was calculated as described below. Weight of empty dish $=\mathrm{W}_{1}$, Weight of dish + sample before drying $=\mathrm{W}_{2}$, Weight of dish + sample after drying $=\mathrm{W}_{3}$, Weight of sample only before drying $=\mathrm{W}_{2}-\mathrm{W}_{1}=\mathrm{WA}$, Weight of sample only after drying $=\mathrm{W}_{3}-\mathrm{W}_{1}=\mathrm{WB}$, Moisture Content $=\mathrm{WA}-\mathrm{WB}$.

$\%$ Moisture content $=\frac{\text { Moisture content }}{W A} \times 100$.

Ash content. A clean, dry and empty crucible was weighed. Dried leaf sample (2 g) was weighed into the crucible. The crucible was put into the muffle furnace and the leaves were incinerated at $600{ }^{\circ} \mathrm{C}$ for $5 \mathrm{~h}$. Thereafter, the furnace was allowed to cool and the crucibles were brought out using safety tongs. The crucibles were cooled in a desiccator and the weight of the crucible and the ash inside was determined. The ash content was calculated as follows. Weight of the empty crucible $=W_{1}$, Weight of the crucible and sample $=W_{2}$, Weight of sample only = $\mathrm{W}_{2}-\mathrm{W}_{1}$, Weight of crucible and ash $=\mathrm{W}_{3}$, Weight of ash only $=\mathrm{W}_{3}-\mathrm{W}_{1}$.

$$
\% \text { Ash Content }=\frac{W 3-W 1}{W 2-W 1} \times 100 .
$$

Crude fat content. The crude fat content of the sample was determined using a Soxhlet extractor.

Two grams of the sample was weighed into a muslin cloth and the cloth was tied up. The cloth was then placed into the extracting chamber of Soxhlet extractor. A dried and empty boiling flask was weighed. Petroleum ether $(400 \mathrm{ml})$ was put into the boiling flask and placed into a heating mantle. The whole Soxhlet apparatus was set up and left to run for 3-4 h until the colour of the solvent in the extraction chamber of the Soxhlet extractor was clear. Afterwards, the solvent in the flask was evaporated leaving behind the fat. The weight of the flask containing the fat was then determined and the crude fat 
content calculated as shown below. Weight of sample $=\mathrm{W}_{1}$, Weight of the empty flask $=\mathrm{W}_{2}$, Weight of the flask and fat $=\mathrm{W}_{3}$, Weight of fat only $=\mathrm{W}_{3}-\mathrm{W}_{2}$.

$$
\% \text { crude fat }=\frac{W 3-W 2}{W 1} \times 100 \text {. }
$$

Crude fibre content. Two grams of dried, defatted sample was weighed. The sample was then boiled in $200 \mathrm{ml}$ of $1.25 \%$ sulphuric acid for $30 \mathrm{~min}$ then filtered and rinsed with water in order to remove the acid. The residue was then boiled in $200 \mathrm{ml}$ of $1.25 \%$ sodium hydroxide for another $30 \mathrm{~min}$, filtered and rinsed with water to remove the alkali. The final residue was then dried, weighed and ashed in the muffle furnace at $600{ }^{\circ} \mathrm{C}$ for $4 \mathrm{~h}$. Afterwards, the ash was the cooled in a desiccator and weighed. The crude fibre content is then calculated as shown below. Weight of sample $=\mathrm{W}_{1}$, Weight of dried final residue $=W_{2}$, Weight of ashed residue $=W_{3}$, Weight of the crude fibre $=\mathrm{W}_{2}-\mathrm{W}_{3}$,

$$
\% \text { crude fibre }=\frac{W 2-W 3}{W 1} \times 100 .
$$

Crude protein content. Sample (1.5 g) was weighed into the Kjedahl digesting flask. Concentrated sulphuric acid (20 ml) was carefully dispensed into the flask and a tablet of selenium catalyst was also added to the mixture in the flask. The flask together with its contents was then transferred into the Kjedahl digesting block inside the fume cupboard. The heater was turned on and the set-up was left to run for about $5 \mathrm{~h}$ until the liquid was and free from black or brown colour. After digestion, the flask was left to cool and the contents were washed into a conical flask with $100 \mathrm{mls}$ of distilled water. The conical flask was then placed into the distillation system and $2 \%$ boric acid was sucked into the flask. $40 \%$ of sodium hydroxide was also sucked into the mixture and then allowed to distil. After about $150 \mathrm{mls}$ has distilled over, the delivery tube was washed down into the conical flask and 3 drops of methyl red indicator was added. Then, the mixture was titrated against $0.05 \mathrm{M}$ sulphuric acid, the titre value recorded and together with other parameters used to determine the percentage nitrogen content which is multiplied by a conversion factor of 6.25 to obtain the percentage crude protein present. A blank was also run along with the sample.

$\%$ Total nitrogen $=$

$$
=\frac{(V s-V B) \times C A \times 0.0014 \times 100}{\text { Weight of sample }} \text {, }
$$

$\%$ Crude Protein $=\%$ Nitrogen $\times 6.25$, where $V_{\mathrm{S}}$ - volume of acid required to titrate the sample (ml), $V_{\mathrm{B}}$ - volume of the acid required to titrate the blank (ml), CA - concentration of the acid $\left(\mathrm{mol} / \mathrm{dm}^{3}\right)$.

Carbohydrate determination. Carbohydrate content was determined by subtracting the sum of percentage moisture, ash, fat, fibre and protein content from $100 \%$ as shown below:

$\%$ carbohydrate $=100-(\%$ fibre $+\%$ moisture $+\%$ protein $+\%$ fat $+\%$ ash).

\section{Experimental feed preparation}

The experimental feed for this study was prepared using dried-pulverized C. olitorius leaf sample (DPCS) as 10\% level at the expense of an equivalent amount corn starch in the commercial pelleted rat chow. The constituent of the rat chow was as follows:

Composition of rat chow in $\mathrm{g} / 100 \mathrm{~g}$ (constituent, \%): corn starch -50 , sucrose -15 , soy bean 20 , groundnut oil -10 , mineral mix -3.7 , vitamin mix -1.3 , total $-100 \%$.

Mineral mix in $\mathrm{g} / 100 \mathrm{~g}$ : calcium phosphate 49.5 , sodium powder -11.8 , potassium sulphate 5.2 , sodium chloride -7.1 , magnesium oxide -2.4 , potassium citrate -22.4 , ferric citrate -0.6 , magnesium carbonate -0.35 , zinc carbonate -0.16 , potassium iodate -0.001 , sodium selenate -0.001 , choline chloride -0.5 , chromium potassium sulphate -0.055 .

Vitamin mix contain the following in $\mathrm{g} / 100 \mathrm{~g}$ : thiamine $\mathrm{HCl}-0.6$, riboflavin -0.6 , niacin -0.3 , calcium panthothenate -0.6 , biotin -0.01 , vitamin $\mathrm{B}_{12}-0.1$, vitamin $\mathrm{D}_{3}-0.025$, vitamin $\mathrm{E}$ acetate -1 , vitamin A acetate -0.08 .

Nutrient composition of rat chow (content of rat chow, \%): crude protein -22.02 , crude oil -4.25 , crude fibre -3.02 , ash -7.5 , sand silica -1.38 , calcium -0.8 , phosphorus -0.6 , glucose -2.46 , vitamins -1.8 , corn starch -56.17 .

\section{Animal study}

Thirty male albino rats (Wistar strain) weighing between 150-200 g were obtained from Babcock University Animal Facility were allowed to acclimatize for 14 days. Animals were maintained and cared for following the National Institute of Health regulation on Laboratory Animal Care and Use Guidelines [11]. Twenty one rats were randomly selected and induced with diabetes through intraperitoneal administration of $130 \mathrm{mg} / \mathrm{kg}$ body weight alloxan drug in accordance to the method described by Sharma et al. [12]. After $24 \mathrm{~h}$ of diabetes induction, rats that 
had a fasting blood glucose level above $200 \mathrm{mg} / \mathrm{dl}$ were evenly distributed into three groups: 1 - control rats; 2 - untreated diabetic rats; 3 - diabetic rats fed with $80 \mathrm{~g}$ of $C$. olitorius leaves as supplement for 14 days. Daily feed supplied to rats in each group and the leftovers were weighed.

The blood glucose levels of the rats were checked before induction, after induction and after feeding, using Accu-Chek diagnostic glucometer kit. At the expiration of the experiment, the rats were anesthetized with chloroform and sacrificed. This was followed by collection of blood samples through cardiac puncture using hypothermal syringe into heparin bottles. Liver organs were removed for biochemical analysis.

Collection of tissue samples. The liver of each animal was examined for any observable morphological changes, excised, trimmed to remove excess tissue, rinsed with $1.15 \% \mathrm{KCl}$ and homogenized in $0.1 \mathrm{M}$ phosphate buffer and centrifuged at $3000 \mathrm{~g}$ for 15 min to obtain supernatant [13]. The supernatant was then subjected to lipid profile analysis using a spectrophotometric method with the aid of Randox kits (Randox Diagnostics, USA).

Statistical analysis. This was done with the aid SPSS for windows: SPSS Inc., Chicago, Standard version 17.0 to determine difference between mean using Analysis of Variance (ANOVA). Data were reported as mean \pm Standard error of mean.

\section{Results and Discussion}

Table 1 showed that in $C$. olitorius leaf, the moisture content was the highest $(82.0 \pm 2.3 \%)$, while crude fat was the lowest $(1.0 \pm 0.5 \%)$. Phytochemical screening of the extract revealed the presence of alkaloids, anthraquinones, cardiac glycosides, saponins, tannins, phenols, phlobatannins and flavonoids.

Table 2 indicated that the plasma glucose concentrations in the (DPCS) fed animals decreased significantly $(P<0.01)$ after the first and second weeks
Table 1. Proximate analysis of C. olitorius leaf

\begin{tabular}{l|c}
\hline \multicolumn{1}{c|}{ Parameters } & Composition (\%) \\
\hline Moisture content & $82.0 \pm 2.3$ \\
Ash content & $2.6 \pm 1.8$ \\
Crude fibre & $2.5 \pm 1.0$ \\
Crude fat & $1.0 \pm 0.5$ \\
Crude protein & $5.2 \pm 1.0$ \\
Carbohydrate & $7.0 \pm 0.5$ \\
\hline
\end{tabular}

of post-treatment when compared to the animals induced diabetics without treatment (control).

Data in Fig. 1 showed that the concentrations of plasma total cholesterol $(108.6 \pm 1.74 \mathrm{mg} / \mathrm{dl})$, LDLcholesterol $(55.98 \pm 15.10 \mathrm{mg} / \mathrm{dl})$ and triglyceride $(82.44 \pm 21.22 \mathrm{mg} / \mathrm{dl})$ in DPCS fed animals were significantly $(P<0.05)$ reduced compared to the plasma total cholesterol (137.51 $\pm 0.72 \mathrm{mg} / \mathrm{dl})$, LDLcholesterol (76.82 $\pm 2.30 \mathrm{mg} / \mathrm{dl})$ and triglyceride $(127.03 \pm 20.66 \mathrm{mg} / \mathrm{dl})$ in untreated diabetic animals. The mean plasma HDL-cholesterol concentration in DPCS fed animals $(71.19 \pm 18.22 \mathrm{mg} / \mathrm{dl})$ was significantly $(P<0.05)$ elevated compared to that of untreated diabetic animals (31.62 $\pm 0.90 \mathrm{mg} / \mathrm{dl})$.

Further investigation of the lipid content of the liver tissue indicated that the animals fed with DPCS had a significantly $(P<0.05)$ decreased liver concentrations of total cholesterols $(126.04 \pm 18.54 \mathrm{mg} / \mathrm{dl})$ and triglycerides (218.38 $\pm 22 \mathrm{mg} / \mathrm{dl})$ compared to the total cholesterol (331.84 \pm 0.77$)$ and triglyceride $(1093.7 \pm 395.63 \mathrm{mg} / \mathrm{dl})$ of untreated diabetic animals (Fig. 2).

Phytotherapy has remained the primary mainstay of treatment in developing countries. Several studies had also indicated that plant-based foods could also confer therapeutic benefits in addition to its nutritive advantages [14].

In this study, the therapeutic potential of C. olitorius leaf against an alloxan-induced diabetic

Ta b le 2. Effects of C. olitorius leaf on plasma glucose concentrations in alloxan-induced diabetic rats

\begin{tabular}{l|c|c|c|c}
\hline $\begin{array}{c}\text { Treatment } \\
\text { groups }\end{array}$ & $\begin{array}{c}\text { Pre-induction } \\
\text { of diabetes (mg/dl) }\end{array}$ & $\begin{array}{c}\text { 24 h after post- } \\
\text { induction of } \\
\text { diabetes (mg/dl) }\end{array}$ & $\begin{array}{c}\text { One week after } \\
\text { treatment (mg/dl) }\end{array}$ & $\begin{array}{c}\text { Two weeks after } \\
\text { treatment (mg/dl) }\end{array}$ \\
\hline Normal & $87.5 \pm 5.04^{\mathrm{a}}$ & $91.0 \pm 0.56^{\mathrm{b}}$ & $91.5 \pm 0.23^{\mathrm{d}}$ & $94.5 \pm 4.45^{\mathrm{g}}$ \\
Control & $81.5 \pm 2.20^{\mathrm{a}}$ & $367.0 \pm 8.85^{\mathrm{c}}$ & $357.5 \pm 5.56^{\mathrm{e}}$ & $313.5 \pm 8.03^{\mathrm{h}}$ \\
DPCS & $79.5 \pm 0.34^{\mathrm{a}}$ & $357.5 \pm 1.58^{\mathrm{c}}$ & $187.0 \pm 0.56^{\mathrm{f}}$ & $99.0 \pm 4.48^{\mathrm{g}}$ \\
\hline
\end{tabular}

Different alphabets in each column are significantly different from each other at $P<0.01$. 


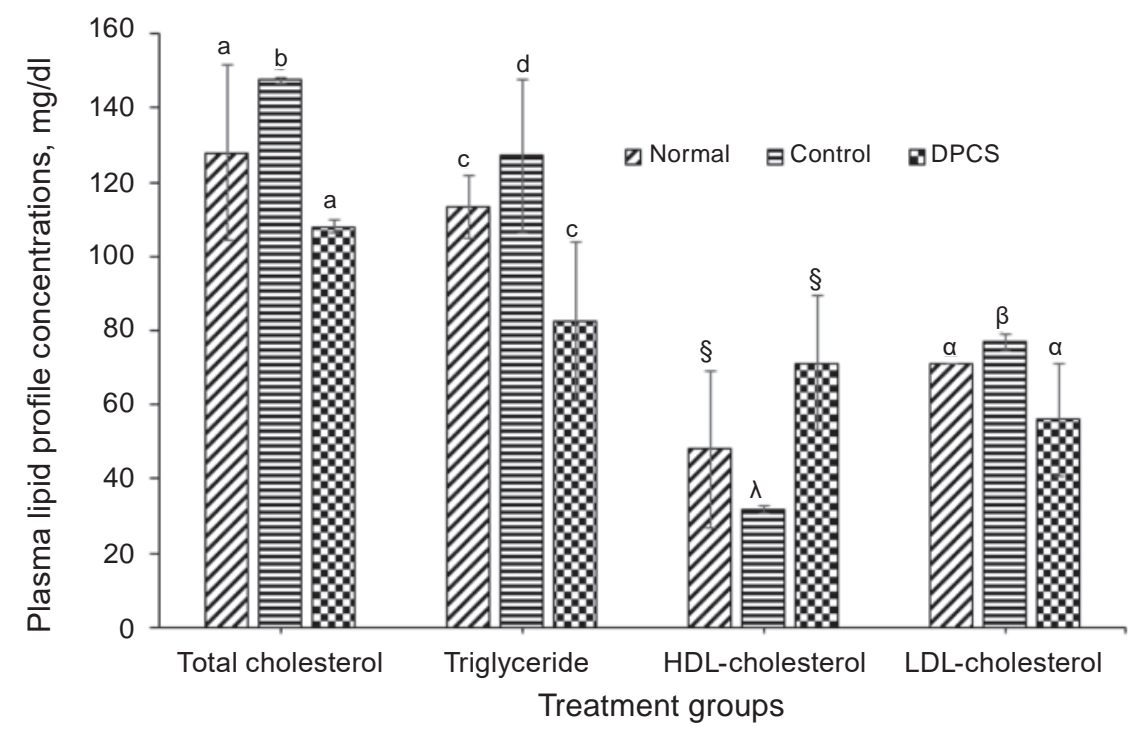

Fig. 1. Effects of C. olitorius on plasma lipid profile of alloxan-induced diabetic rats

condition in rats was investigated. The study showed that $C$. olitorius leaf caused a reduction in plasma glucose concentrations of diabetic rats. This indicates that $C$. olitorius leaf could contain hypoglycemic compounds. Previous study had shown that hypoglycemic effect of plant leaves may probably be due to the presence of flavonoids, alkaloids, terpenoids, steroids and complex carbohydrates [15]. Similar phyto-constituents were also detected in this study.

Proximate composition of $C$. olitorius leaves revealed an appreciable amount of crude fibre content. It has been shown that fibre could contribute in the management of diabetes through chelation of intestinal glucose thus reducing the level of blood glucose [16]. Furthermore, C. olitorius leaf fed animals had a decreased plasma and liver cholesterol contents compared with untreated diabetic animals. This suggests that $C$. olitorius leaf may possess hypocholesterolemic property. The fibre content of this plant may play contributory role in the reduction of cholesterol content in diabetic rats. Plant fibre has been reported to trap bile in the intestine. This may leads to the production of more bile from cholesterol thus reducing the concentration of circulating blood cholesterol [16].

The accumulation of blood cholesterol in the diabetic rats may be due to the increased cholesterol

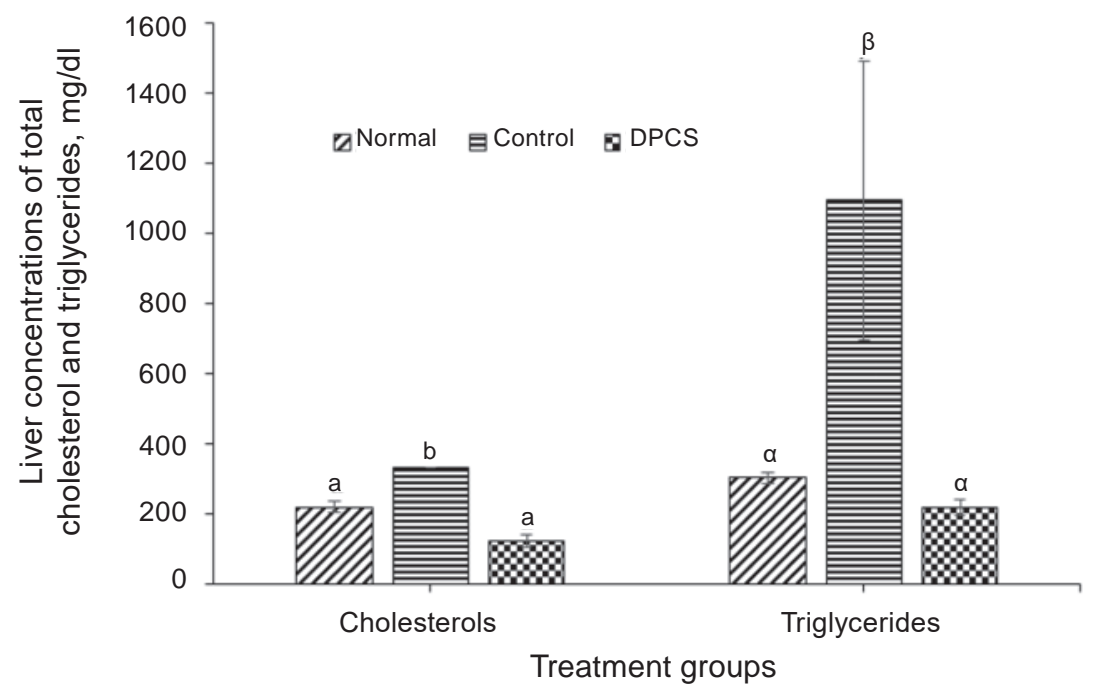

Fig. 2. Effects of C. olitorius on liver total cholesterol and triglycerides concentrations in alloxan-induced diabetic rats 
biosynthesis in the liver and a reduction in the concentration of acy1-CoA: cholesterol-O-acyltransferase (ACAT), the enzyme that esterifies cholesterol in the cells of the body [17]. All these could led to an elevated plasma cholesterol concentration in the diabetic rats. C. olitorius probably reduced the circulating plasma cholesterol concentration by inhibiting the biosynthesis of cholesterol in the liver or by reducing the amount of cholesterol that is absorbed into the bloodstream from the gastrointestinal tract.

C. olitorius leaf feed had a decreased plasma and liver triglyceride concentrations compared to those of untreated diabetic rats. This indicated that C. olitorius feed may possess hypolipidemic property. It has been suggested that an elevated triglyceride level may be due to insulin deficiency which results in faulty glucose utilization with its consequent hyperglycemic condition in animals. In addition, there may also be mobilization of fatty acids from adipose tissue to the liver [18]. The reduced plasma and liver triglyceride concentrations in the rats fed with C. olitorius was perhaps due to improved uptake and utilization of the circulation plasma glucose leading to decreased triglyceride biosynthesis and also a reduction in fatty acid mobilization from adipocytes.

Furthermore, there was a significant decrease in plasma LDL-cholesterol concentration in the diabetic rats treated with C. olitorius feed compared with the untreated diabetic rats. This suggest that $C$. olitorius may possess hypocholesterolemic property. Flavonoids may positively influence health through their well-documented effects on cellular antioxidant status and inflammation [19] Previous study had shown that agents with hypocholesterolemic activity may act through disruption of insulin secretion in the diabetic rats which may results into the inability of the LDL-receptors take up circulating plasma LDL-cholesterol [20]. In addition, the levels of plasma HDL-cholesterol which were elevated in animals that feed on $C$. olitorius diet when compared to those of untreated diabetic rats, lends credence to the report Mahdieh et al [21], that intakes of phytochemical-rich foods have beneficial effects on lipid profiles and cardiovascular disease (CVD). This study has shown that $C$. olitorius leaves possesses hypoglycemic and hypolipemic effects against alloxan-induced diabetic rats. Also the phytochemical present in the plant was associated with the aforementioned improvement of total cholesterol, triglycerides, LDL-cholesterol and plasma HDLcholesterol.
Conflict of interest. Authors have completed the Unified Conflicts of Interest form at http://ukrbiochemjournal.org/wp-content/uploads/2018/12/coi_ disclosure.pdf and declare no conflict of interest.

Acknowledgement. We express sincere gratitude to Babcock University Administration for providing the facility for conducting this study. We also thank Mr. O. Gisanrin and Mrs. Anyasor C. for their immense technical assistance during the course of this research.

\section{ГІПОГЛІКЕМІЧНИЙ I ГІПОЛІПІДЕМІЧНИЙ ЕФЕКТИ ЛИСТЯ CORCHORUS OLITORIUS ЗА АЛЛОКСАНІНДУ КОВАНОГО ДІАБЕТУ В ЩУРІВ}

\author{
G. N. Anyasor, O. O. Adekanye, \\ O. T. Adeyemi, O. Osilesi
}

Department of Biochemistry, Benjamin S.

Carson School of Medicine, Babcock University, Ilisan-Remo, Ogun State, Nigeria; e-mail: olaoluwatemi@yahoo.com

Листя Corchorus olitorius в Африці, на Близькому Сході і в Південній Азії споживають в їжу. Досліджено гіпоглікемічний і гіполіпідемічний ефекти листя C. olitorius у щурів з алоксаніндукованим діабетом. Щурів-альбіносів (21) було розподілено на три групи: група 1 - контроль; група 2 - діабетичні щури і група 3 - діабетичні щури, які отримували листя C. olitorius з їжею. У щурів із групи 3 спостерігали значне зниження рівня глюкози $(P<0,01)$, LDL-холестеролу, загального холестеролу і тригліцеридів у плазмі крові порівняно з показниками в діабетичних щурів, які не отримували C. olitorius. Дійшли висновку, що листя C. olitorius мають гіпоглікемічні і гиполіпідемічні властивості.

Ключові слова: Corchorus olitorius, алоксаніндукований діабет, гіпоглікемічний та гіполіпідемічний ефекти, холестерол, тригліцериди.

\section{References}

1. Velempini P, Riddoch I, Batisani N. Seed treatments for enhancing germination in wild okra (Corchorus olitorius). Exp Agric. 2003; 39(4): 441-447.

2. Adegoke AA, Adebayo-Tayo BC. Phytochemical composition and antimicrobial effects of 
Corchorous olitorius leaf extracts on four bacterial isolates. $J$ Med Plant Res. 2009; 3(3): 155-159.

3. Mahbubul MI. Biochemistry, medicinal and food values of Jute (Corchorus capsularis L. and C. olitorius L.) leaf: a review. Int $J$ Enhanced Res Sci Technol Eng. 2013; 2(11): 35-44.

4. Abdul S, Kaushik C. Jute-A biological elixir with multifaceted applications: An overview. Int J Res Pharm Sci. 2015; 6(4): 323-332.

5. Wadkar KA, Magdun CS, Patil SS, Naikwade NS. Anti-diabetic potential and Indian medicinal plants. J Herbal Med Toxicol. 2008; 2(1): 45-50.

6. Yakubu MT, Akanji MA, Nafiu MO. Anti-diabetic activity of aqueous extract of Cochlospermum planchonii root in alloxan-induced diabetic rats. Cameroon J Exp Biol. 2010; 6(2): 91-100.

7. Trease GE, Evans WC. Pharmacognosy: a Physician's Guide to Herbal Medicine. 13th ed. London: Bailliere Tindall, 1989. P. 176-180.

8. Harbone JB. Phytochemical Methods. A Guide to Modern Technique of Plant Analysis. London: Chapman and Hall Ltd., 1973. P. 49-188.

9. Sofowora A. Medicinal Plants and Traditional Medicine in Africa. 2nd ed. Ibadan, Nigerian: Spectrum Books Ltd., 1993.289 p.

10. Association of Official Analytical Chemist (AOAC). Official Methods of Analysis. Washington DC, United States: Association of Official Analytical Chemists, 1990; P. 20-26.

11. Sharma SR, Dwivedi SK, Swarup D. Hypoglycemic antihyperglycemic and hypolipidemic activities of Cesalphinia bounducella seed in rats. $J$ Ethnopharmacol. 1997; 58(1): 39-44.

12. Kjellén L, Bielefeld D, Hook M. Reduced sulfation of liver heparan sulfate in experimentally diabetic rats. Diabetes. 1983; 32(4): 337-342.
13. Kingsley O, Marshall AA. Medicinal potential of Acalypha wilkesiana Leaves. Adv Res. 2014; 2(11): 655-665.

14. Tuso PJ, Ismail MH, Ha BP, Bartolotto C. Nutritional update for physicians: plant-based diets. Perm J. 2013; 17(2): 61-66.

15. Mohan Y, Jesuthankaraj GN, Thangavelu NR. Antidiabetic and antioxidant properties of Triticum aestivum in streptozotocin-induced diabetic rats. Adv Pharmacol Sci. 2013; 2013: Article ID 716073.

16. Hamid RHM, Hamid RE. Screening of bile acid binding capacity of some synthetic dietary fiber. Global Veterinaria. 2013; 10(4): 485-490.

17. Katsuren K, Tamura T, Arashiro R, Takata K, Matsuura T, Niikawa N, Ohta T. Structure of the human acyl-CoA:cholesterol acyltransferase-2 (ACAT-2) gene and its relation to dyslipidemia. Biochim Biophys Acta. 2001; 1531(3): 230-240.

18. Duwaerts CC, Maher JJ. Macronutrients and adipose-liver axis in obesity and fatty liver. Cell Mol Gastroenterol Hepatol. 2019; 7(4): 749-761.

19. Bao L, Hu L, Zang Y, Wang Y. Hypolipidemic effects of flavonoids extracted from Lomatogonium rotatum. Exp Ther Med. 2016;1 1(4): 1417-1424.

20. Kawai Y, Sato-Ishida R, Motoyama A, Kajinami K. Place of pitavastatin in the statin armamentarium: promising evidence for a role in diabetes mellitus. Drug Des Devel Ther. 2011; 5: 283-297.

21. Golzarand M, Mirmiran P, Bahadoran Z, Alamdari S, Azizi F. Dietary phytochemical index and subsequent changes of lipid profile: A 3-year follow-up in Tehran Lipid and Glucose Study in Iran. ARYA Atheroscler. 2014; 10(4): 203-210. 